\title{
Impact of Intervention Program on Nursing Performance Provided for Neonates with Sepsis at Intensive Care Units
}

\author{
NaglaaFathy Mohamed Belal(2), Safaa Salah Ismail(1), Madiha Hassan Bayoumi(2) \\ (1)Pediatric Nursing Department, Faculty of Nursing, Helwan University, Egypt \\ (2)Pediatric Nursing Department, Faculty of Nursing, Benha University, Egypt
}

\section{ABSTRACT}

Background: Sepsis imposes a major threat to newborn infants. It is estimated that sepsis causes over half a million neonatal deaths annually, thereby accounting for about $15 \%$ of all neonatal deaths worldwide. This study aimed to: Assess the impact of intervention program on nursing performance provided for neonates with sepsis at Intensive Care Units. Setting: This study was conducted at Neonatal Intensive Care Units in Benha University Hospital, Benha Specialized Pediatric Hospital and Benha Teaching Hospital. Design: A quasi- experimental design was used. Sample: A purposive sample of 100 nurses included in the study working at the previously mentioned settings. Tools: The first tool is a pre-designed questionnaire to assess nurses' knowledge about neonatal sepsis, the second tool was observational checklist to assess nurse's performance for neonates with sepsis. Results: revealed that, the mean age of the studied nurses was $23.9 \pm 3.8$ years and there was a positive correlation between nurses' knowledge and practices scores post program implementation compared with preprogram implementation. Conclusion: Nurses' performance are significantly improved post program implementation that reflects the importance of continuous and in- service education for nurses working at Neonatal Intensive Care Units. Recommendation:Collaboration and continuing education of the staff in the NICUs are vital to improve the quality of care provided for neonates with sepsis.

Key words: Neonatal sepsis, Neonatal intensive care units, Intervention program, nursing performance.

\section{INTRODUCTION}

Neonatal sepsis is a major health problem as it is responsible for $30-50 \%$ of the total neonatal deaths in developing countries. It is estimated that up to $20 \%$ of the neonates develop sepsis and approximately $1 \%$ die from sepsis related causes (Shashi et al., 2013).

Neonatal sepsis, or primary infection of the bloodstream (BSI) is a clinical syndrome characterized by a systemic inflammatory response (SIR), with or without evidence of a suspected or confirmed infection. It is one of the more frequent infectious pictures in the neonatal period, and is the one which most raises morbidity and mortality (Santos et al., 2014).

Neonatal sepsis is classified as earlyonset neonatal sepsis (EONS) and late-onset neonatal sepsis (LONS). In EONS, the newborn shows symptoms in the first three days of life, less than 72 hours of age, and it is related to maternal risk factors where the bacteria found in the cultures are present in 
the birth canal. In LONS, the symptoms occur from the fourth day of life, with more than 72 hours of age. This form of sepsis is related to neonatal factors and generally affects newborns who are hospitalized in Neonatal Intensive Care Units (NICUs), which means that it is acquired from the hospital environment (Camacho et al., 2013).

Late-onset neonatal sepsis is strongly associated with the procedures and contamination present in the NICUs. Preterm newborns are infected with microorganisms by indirect human contact with the contaminated environment. Consequently, horizontal transmission is a major factor in the development of LONS and preventive interventions should be carried out in the NICUs in order to minimize this exposure (Silva et al., 2015).

The signs and symptoms of neonatal sepsis are nonspecific. These include hyperthermia or hypothermia, respiratory distress including cyanosis and apnea, feeding difficulties, lethargy or irritability, hypotonia, seizures, bulging fontanel, poor perfusion, bleeding problems, abdominal distention, hepatomegaly, gauiac- positive stools, unexplained jaundice (Shah \& Padbury, 2014).

Nurses provide the direct care and have the ability to impact on neonate's outcomes, so that, teaching nurses about sepsis is considered fundamental to improve neonate's care safety and outcomes. To make this a reality, a "competent and confident workforce" is needed to address infection control practices and reduce healthcareassociated infections (HAIs). An evidencebased educational intervention on sepsis will help nurses become more competent in the early identification of clinical signs of sepsis, and more confident in initiating the recommended Surviving Sepsis Campaign bundles or guidelines for best practice. implementation of education, programs, and interventions in a systematic way to be sure that healthcare professionals can provide quality care (Burnett et al., 2013).

Prevention against neonatal sepsis includes; strict hand-hygiene practices, careful aseptic procedures in the management of intravenous lines, skin care, judicious use of antibiotics, promoting early enteral nutrition (as opposed to parenteral), preferably using breast milk (i.e., to enhance the infant's own gastrointestinal immune defenses) and minimizing invasive interventions (e.g., prompt removal of central venous catheters (CVCs) and reducing mechanical ventilation) (Marchant et al., 2013).

\section{Significance of the study}

The most common diagnosis in NICUs presumed neonatal septicemia and improper infection control measures provided by the care-givers that increasing the rate of infection. However, the cases of the neonatal sepsis at Benha Teaching Hospital during the period from 2012-2014 were 71 cases and the mortality rate was 13 cases which account $18 \%$ from these cases. On the other hand the cases of the neonatal sepsis at Benha University Hospital during the same period were 56 cases and the mortality rate was about 6 cases or $10.7 \%$ from these cases. In addition, the number of cases with neonatal sepsis in Specialized Pediatric Hospital from the period 2012-2014 was 198 cases and the mortality rate is about 56 cases $(28 \%$ from these cases) (Hospital Statistical Department, 2014). So that, it is important to assess the impact of intervention program on nursing performance provided for neonates with sepsis at Neonatal Intensive Care Units, as those nurses play an important role in eliminating spread of infection.

\section{Aim of the study}

This study aimed to assess the impact of intervention program on nursing 
performance provided for neonates with sepsis at Neonatal Intensive Care Units through:-

1-Developingand implementing the impact of intervention program on nursing performance regarding to care of neonates with sepsis.

2-Assessing nurses' knowledge regarding the care provided for neonates with sepsis.

3-Evaluating nurses' performance regarding nursing management forneonates with sepsis.

\section{Hypothesis}

Nurses who receive an intervention program about care toward neonatal sepsis may become more qualified in their interventions.

\section{Subjects and Methods}

Subjects and methods for this study are portrayed under four main designs as follows:

I- Technical design: The technical design for the study included research design, setting of the study, subjects as well as tools of data collection.

\section{A) Research design:}

A quasi experimental design was utilized for conducting the study.

\section{B) Research settings:}

This study was conducted at Neonatal Intensive Care Units in Benha University Hospital, Benha Specialized Pediatric Hospital and Benha Teaching Hospital.

\section{C) Subjects:}

A purposive sample composed of one hundred nurses were included in the study from the previously mentioned settings where; 20 nurses from Benha University Hospital, 30 nurses from Benha Teaching Hospital and 50 nurses from Benha Specialized Pediatric Hospital. Criteria of nurses were their experience not less than one year at NICUs. Regardless their age dealing with neonates suffering from sepsis.

Neonates under the following criteria were their age less than one month, suffering from sepsis without other complication.

\section{D) Tools of data collection:}

Two tools were used for data collection:-

\section{Tool I: A questionnaire Tool:-}

A pre-designed questionnaire sheet (pre/post program implementation), it was developed by the researcher and divided into two parts:

Part one: Concerned with characteristics of the studied nurses. It was developed to collect data about nurse's age, sex, qualification, years of experience, place of work, marital status and training program about infection control measures in NICUs.

Part two: This part was developed to assess nurses' knowledge about neonatal sepsis. It was written in a simple Arabic language in the form of opened-ended and yes or no questions and included twelve questions: regarding meaning, signs and symptoms, risk factors, disease contribute to neonatal sepsis, types, complications, treatment, mode of transmission of infection, methods of prevention from infection, isolation measures and methods used with isolated neonate. And thirty questions to assess nurses' knowledge about practices before, during and after caring for neonates 
with sepsis at NICUs in the form of openedended.

\section{Scoring system:}

The total score level for the questionnaire tool was one hundred marks (100\%). The nurses' knowledge was checked with a model key answer and accordingly their knowledge was categorized into either:

\section{Scoring system for level of total} knowledge about neonatal sepsis:

A score of two was given for good answer and one for average answer and a zero for a poor answer. For each part, the scores of the items were summed up and the total divided by number of the items, giving a mean score for the part. These scores were converted into a percent score, mean and standard deviations were computed. The nurses' knowledge was considered good if the percent score was $75 \%$ or more, average if scored $50 \%<75 \%$ and poor if scored less than $50 \%$.

Scoring system: Nurses' knowledge about nurses' practices before, during and after dealing with neonates with sepsis:

A score of one was given for correct answer and a zero for an incorrect answer. For each part, the scores of the items were summed up and the total divided by number of the items, giving a mean score for the part. These scores were converted into a percent score, mean and standard deviations were computed. The nurses' knowledge was considered done if the percent score is $75 \%$ or more and not done if scored less than $75 \%$.

\section{Tool II: Observational checklist:-}

Nurses' observational checklist was used to assess the actual nurses' involvement performance in caring for neonates with sepsis at NICUs, this tool was adopted from Bowden \& Greenberg, (2012), Khadka et al., (2013), Lindh et al., (2014) and Egyptian Ministry of Health and Population, (2015)which included sixteen procedures namely, nurses' observational checklist for measuring vital signs, growth measurements, care for neonates, care of ventilator, care of incubator, hand hygiene, wearing protective clothes, intravenous cannula, administration of IV fluid, preparation of mixed solution, breast feeding, artificial feeding, gavage feeding, specimens collection, naso- tracheal suctioning and oxygen therapy.

-Time consumed for assessment and evaluation of nurses' practices was approximately 60 minutes.

- Each nurse was observed during the actual involvement practices for neonates' care, using the observation checklists that were filled in by the researcher.

- Each nurse was observed for three times and then the average score was obtained.

- The total number of procedures was 16 , each procedure score about 10 to make total score of 300 equal $100 \%$

Scoring system: Nurses' practice: a score of one was given for competent and a zero for an incompetent For each part, the scores of the items were summed up and the total divided by number of the items, giving a mean score for the part. These scores were converted into a percent score and mean and standard deviations were computed. The nurses' knowledge was considered done if the percent score is $75 \%$ or more and not done if scored less than $75 \%$.

\section{II- Operational design:-}

\section{1-Preparatory phase:}

Review of the past and current local and international related literature using 
articles, journals, scientific periodicals magazines and books, was done to develop the study tools and to get acquainted with various aspects of the research problem.

\section{2- Pilot study:}

A Pilot study was included $10 \%$ of the total study nurses. It was conducted to test the practicability, applicability and timing of data collection. No radical modifications were done to the questionnaire. Therefore, the sample of pilot study was included in the total study nurses.

\section{3- Validity \& reliability tests:}

The study tools were revised by a jury which consisted of three experts in the field of pediatric nursing to determine the extent to which the items in the questionnaire were related to each other.

\section{4- Field work:}

The actual field work was carried out over 6 months starting from the first week of June, 2015 up to the end of November, 2015.

The researcher was available three days/week from 9 am to $8 \mathrm{pm}$ by rotation in the previously mentioned setting.

\section{A) Assessment phase}

-The researcher had presented to the NICUs one day for two shifts for each setting.

- The researcher introduced herself to the nurses and explained the purpose of the study and the importance of neonatal sepsis prevention.

- Each day the researcher spent 12 hours. Each nurse was interviewed using predesigned interviewing questionnaire to obtain the data needed; each interview lasted 10-15 minutes.
- An interview was conducted to collect baseline data from nurses regarding knowledge about neonatal sepsis and their actual involvement practices through observation before, during and after caring for neonates with sepsis. Nurses were observed and evaluated for the care they provided to neonates with sepsis.

- Areas of weakness in nurses' knowledge and practices were identified and designing program objectives were set as follows.

\section{Overall aims of nursing care program implementation:}

This program implementation included in knowledge and performance needed to provide nursing care for neonates suffering from sepsis.

\section{B) Planning phase:}

The researcher planned the nursing care after a review of literature based on the assessment of nurses' knowledge obtained from the questionnaire sheet and nurse's performance obtained through nurse's observational checklist.

\section{C) Implementation phase:}

The program implementation was implemented at the study settings. A booklet was designed based on level of nurses' knowledge and practices. It contained meaning, signs and symptoms, risk factors, disease contribute to neonatal sepsis, types, complications, treatment, mode of transmission of infection, methods of infection prevention, isolation measures and methods used with isolated neonate.

Twenty teaching sessions were conducted focusing on information included in the booklet. Nurses were divided into 10 groups, 10 nurses in each group. This program was provided in 15 sessions (six sessions for theoretical part and nine sessions 
for practical part). Time for each was 30 minutes for theoretical part and 30-45 minutes for practical part. Sessions given in three days a week (Sunday, Monday and Tuesday) for all hospitals by rotation.

Teaching methods used were lectures, discussion and demonstration /redemonstration. Teaching materials were handout and real equipment.

\section{D) Evaluation phase:}

The post- program implementation was administered to assess participating nurses' knowledge and practices, using the same tools of the pre- program implementation. Evaluation of nurses' knowledge and practices was conducted immediately postprogram implementation.

\section{III- Administrative design:-}

An official permission to carry out the study was obtained from director of Benha University, Benha Specialized Pediatric and Benha Teaching Hospitals through a formal letter that was issued from Dean of the Faculty of Nursing at Benha University explaining the purpose of the study and methods of data collection.

\section{Ethical considerations:}

Each study nurse was secured that all gathered data was used for research purpose only. The study sample was informed about the purpose and expected outcomes of the study and they were assured that the study is harmless, their participation was voluntary and they had the right to withdraw from the study at any time without given any reason. They were assured also that anonymity and confidentiality of the obtained data was guaranteed.

\section{IV- Statistical design:-}

The data were collected, revised, coded, organized, categorized, tabulated and analyzed using frequencies, percentage, mean scores, standard deviation and correlation coefficient. Data were presented inform of tables and figures.

Quantitative data was presented by mean and standard deviation (SD). Qualitative data was presented in the form of frequency distribution tables, number and percent. It was analyzed by Chi-square test $\left(\mathrm{x}^{2}\right)$. Significance was considered at:

difference.

- P- value > 0.05 no significant

- P-value $<0.05$ Significant difference.

\section{Results}

Table (1) Find that, the mean age was $23.9 \pm 3.8$ years. As regard nurses qualification, it was found that, $65 \%$ of the studied nurses had bachelor of nursing. Regarding job position of them this table revealed that, $70 \%$ of them were staff nurses. It was clear from this table that, the mean years of experience of the studied nurses were $3.22 \pm 1.9$ years.

Table (2): Regarding to nurses' knowledge about neonatal sepsis this table clarified that, $77 \%, 76 \%, 79 \% \& 77 \%$ of the studied nurses scored good knowledge postprogram implementation compared to preprogram implementation as regard meaning, risk factors, types and treatment of neonatal sepsis, respectively. In addition this table clarified that, $96 \% \& 85 \%$ of them scored good knowledge post- program implementation compared to pre- program implementation as regards neonatal sepsis was infectious disease and methods of prevention from infection of neonatal sepsis, respectively. However, there was statistical significance difference $(\mathrm{P}<0.05)$ between 
pre- program implementation and postprogram implementation.

Table (3): Regarding nurses' knowledge about performance before dealing with neonates with sepsis this table clarified that, $87 \%, 88 \% \& 90 \%$ of the studied nurses washing hands in a septic manner before doing any deep intervention such as the installation of intravenous cannula, observed for hypothermia or hyperthermia and measured of the abdominal circumference every 4 hours post- program implementation compared to pre- program implementation, respectively there was statistical significance difference between pre- program implementation and post- program implementation $(\mathrm{P}<0.05)$.

Table (1): Number and Percentage Distribution of the Studied Nurses regarding to their Characteristics $(n=100)$

\begin{tabular}{|c|c|c|}
\hline Characteristics & No. & $\%$ \\
\hline \multicolumn{3}{|l|}{ Age/ Year } \\
\hline$<20$ & 19 & 19.0 \\
\hline $20-30$ & 70 & 70.0 \\
\hline$\geq 30$ & 11 & 11.0 \\
\hline \multicolumn{3}{|l|}{ mean $\pm \mathrm{SD}$} \\
\hline \multicolumn{3}{|l|}{ Nursing qualification } \\
\hline Diploma in nursing & 14 & 14.0 \\
\hline Specialty diploma & 0.0 & 0.0 \\
\hline Technical institute in nursing & 21 & 21.0 \\
\hline Bachelor & 65 & 65.0 \\
\hline \multicolumn{3}{|l|}{ Job position } \\
\hline Staff nurse & 82 & 82.0 \\
\hline Supervisor nurse & 18 & 18.0 \\
\hline \multicolumn{3}{|l|}{ Years of experience } \\
\hline $1<3$ & 57 & 57.0 \\
\hline $3<5$ & 25 & 25.0 \\
\hline$\geq 5$ & 18 & 18.0 \\
\hline
\end{tabular}


Table (2): Number and Percentage Distribution of Nurses' Knowledge regarding to Neonatal Sepsis pre/post- Program Implementation (n=100)

\begin{tabular}{|c|c|c|c|c|c|}
\hline \multirow[t]{2}{*}{$\begin{array}{l}\text { Knowledge of } \\
\text { neonatal sepsis }\end{array}$} & \multicolumn{2}{|c|}{$\begin{array}{l}\text { Pre- program } \\
\text { implementation }\end{array}$} & \multicolumn{2}{|c|}{$\begin{array}{l}\text { Post- program } \\
\text { implementation }\end{array}$} & \multirow{2}{*}{ P-value } \\
\hline & No. & $\%$ & No. & $\%$ & \\
\hline \multicolumn{6}{|l|}{ Meaning } \\
\hline good & 43 & 43.0 & 77 & 77.0 & \multirow{3}{*}{$\begin{array}{l}24.88 \\
\mathrm{P}<0.05 *\end{array}$} \\
\hline average & 44 & 44.0 & 20 & 20.0 & \\
\hline poor & 13 & 13.0 & 3 & 3.0 & \\
\hline \multicolumn{6}{|c|}{ Signs and symptoms } \\
\hline good & 21 & 21.0 & 74 & 74.0 & \multirow{3}{*}{$\begin{array}{l}57.9 \\
\mathrm{P}<0.05^{*}\end{array}$} \\
\hline average & 76 & 76.0 & 23 & 23.0 & \\
\hline poor & 3 & 3.0 & 3 & 3.0 & \\
\hline \multicolumn{6}{|l|}{ Risk factors } \\
\hline good & 16 & 16.0 & 76 & 76.0 & \multirow{3}{*}{$\begin{array}{l}75.1 \\
\mathrm{P}<0.05^{*}\end{array}$} \\
\hline average & 80 & 80.0 & 20 & 20.0 & \\
\hline poor & 4 & 4.0 & 4 & 4.0 & \\
\hline \multicolumn{6}{|c|}{ Diseases contribute to neonatal sepsis } \\
\hline good & 21 & 21.0 & 73 & 73.0 & \multirow{3}{*}{$\begin{array}{l}54.8 \\
\mathrm{P}<0.05^{*}\end{array}$} \\
\hline average & 72 & 72.0 & 23 & 23.0 & \\
\hline poor & 7 & 7.0 & 4 & 4.0 & \\
\hline \multicolumn{6}{|l|}{ Types } \\
\hline good & 18 & 18.0 & 79 & 79.0 & \multirow{3}{*}{$\begin{array}{l}74.8 \\
\mathrm{P}<0.05 *\end{array}$} \\
\hline average & 69 & 69.0 & 19 & 19.0 & \\
\hline poor & 13 & 13.0 & 2 & 2.0 & \\
\hline \multicolumn{6}{|l|}{ Complications } \\
\hline good & 16 & 16.0 & 73 & 73.0 & \multirow{3}{*}{$\begin{array}{l}70.9 \\
P<0.05 *\end{array}$} \\
\hline average & 48 & 48.0 & 23 & 23.0 & \\
\hline poor & 36 & 36.0 & 4 & 4.0 & \\
\hline \multicolumn{6}{|l|}{ Treatment } \\
\hline good & 14 & 14.0 & 77 & 77.0 & \multirow{3}{*}{$\begin{array}{l}82.3 \\
\mathrm{P}<0.05^{*}\end{array}$} \\
\hline average & 70 & 70.0 & 23 & 23.0 & \\
\hline poor & 15 & 15.0 & 0 & 0.0 & \\
\hline \multicolumn{6}{|c|}{ Neonatal sepsis is infectious disease } \\
\hline good & 71 & 71.0 & 96 & 96.0 & \multirow{3}{*}{$\begin{array}{l}22.6 \\
P<0.05^{*}\end{array}$} \\
\hline average & - & - & - & - & \\
\hline poor & 29 & 29.0 & 4 & 4.0 & \\
\hline \multicolumn{6}{|c|}{ Mode of transmission } \\
\hline good & 16 & 16.0 & 77 & 77.0 & \multirow{3}{*}{$\begin{array}{l}75.1 \\
P<0.05 *\end{array}$} \\
\hline average & 71 & 71.0 & 18 & 18.0 & \\
\hline poor & 13 & 13.0 & 5 & 5.0 & \\
\hline \multicolumn{6}{|c|}{ Methods of prevention from infection } \\
\hline good & 18 & 18.0 & 69 & 69.0 & 53.6 \\
\hline average & 74 & 74.0 & 26 & 26.0 & $P<0.05^{*}$ \\
\hline poor & 8 & 8.0 & 5 & 5.0 & \\
\hline Isolation measures & & & & & \\
\hline good & 4 & 4.0 & 76 & 76.0 & 18.8 \\
\hline average & 71 & 71.0 & 24 & 24.0 & $P<0.05^{*}$ \\
\hline poor & 25 & 25.0 & 0 & 0.0 & \\
\hline
\end{tabular}


Table (3): Number and Percentage of the Studied Nurses' knowledge regarding Performance before dealing with Neonates with Sepsis pre/post- Program Implementation $(\mathbf{n}=\mathbf{1 0 0})$

\begin{tabular}{|c|c|c|c|c|c|}
\hline \multirow{3}{*}{ Knowledge regarding practices } & \multicolumn{2}{|c|}{$\begin{array}{l}\text { Pre- program } \\
\text { implementation }\end{array}$} & \multicolumn{2}{|c|}{$\begin{array}{l}\text { Post- program } \\
\text { implementation }\end{array}$} & \multirow{3}{*}{$\begin{array}{c}\mathrm{X}^{2} \\
\text { P-value }\end{array}$} \\
\hline & Complete & $\begin{array}{c}\text { In- } \\
\text { complete }\end{array}$ & Complete & $\begin{array}{c}\text { In- } \\
\text { complete }\end{array}$ & \\
\hline & No. & $\%$ & No. & $\%$ & \\
\hline $\begin{array}{l}\text { 1-Washing hands and wearing } \\
\text { protective clothes }\end{array}$ & 78.0 & 22.0 & 82.0 & 18.0 & $\begin{array}{c}.500 \\
\mathrm{P}<0.05 *\end{array}$ \\
\hline $\begin{array}{l}\text { 2-Washing hands in a septic manner } \\
\text { before doing any deep intervention such } \\
\text { as the installation of intravenous } \\
\text { cannula }\end{array}$ & 72.0 & 28.0 & 87.0 & 13.0 & $\begin{array}{c}6.90 \\
P>0.05\end{array}$ \\
\hline $\begin{array}{l}\text { 3-Note presence of lethargy and level of } \\
\text { alertness for neonates with sepsis }\end{array}$ & 53.0 & 47.0 & 79.0 & 21.0 & $\begin{array}{c}15.06 \\
\mathrm{P}<0.05 *\end{array}$ \\
\hline $\begin{array}{l}\text { 4-Measuring breathing and note signs of } \\
\text { difficulty in breathing such as increased } \\
\text { rate of breathing and dyspnea }\end{array}$ & 61.0 & 39.0 & 82.0 & 18.0 & $\begin{array}{c}10.82 \\
\mathrm{P}<0.05^{*}\end{array}$ \\
\hline 5-Measure the level of blood glucose & 58.0 & 42.0 & 81.0 & 19.0 & $\begin{array}{c}12.47 \\
\mathrm{P}<0.05^{*}\end{array}$ \\
\hline $\begin{array}{l}\text { 6-Observe signs of inflammation in the } \\
\text { region of the umbilicus such as pus } \\
\text { secretions or offensive odor }\end{array}$ & 57.0 & 43.0 & 81.0 & 19.0 & $\begin{array}{c}13.46 \\
\mathrm{P}<0.05^{*}\end{array}$ \\
\hline $\begin{array}{l}\text { 7-Observe and record the symptoms of } \\
\text { GIT, such as vomiting, abdominal } \\
\text { distension or diarrhea }\end{array}$ & 49.0 & 51.0 & 82.0 & 18.0 & $\begin{array}{c}24.09 \\
\mathrm{P}<0.05^{*}\end{array}$ \\
\hline $\begin{array}{l}\text { 8-Observe for presence of blood in the } \\
\text { stool }\end{array}$ & 48.0 & 52.0 & 84.0 & 16.0 & $\begin{array}{c}28.87 \\
\mathrm{P}<0.05 *\end{array}$ \\
\hline $\begin{array}{l}\text { 9-Observe for hypothermia or } \\
\text { hyperthermia }\end{array}$ & 45.0 & 55.0 & 88.0 & 12.0 & $\begin{array}{c}41.49 \\
\mathrm{P}<0.05^{*}\end{array}$ \\
\hline $\begin{array}{l}\text { 10-Measuring abdominal circumference } \\
\text { every } 4 \text { hours }\end{array}$ & 59.0 & 41.0 & 90.0 & 10.0 & $\begin{array}{c}25.29 \\
\mathrm{P}<0.05 *\end{array}$ \\
\hline $\begin{array}{l}\text { 11- Observe for signs of poor sucking } \\
\text { and lack of feeding }\end{array}$ & 43.0 & 57.0 & 84.0 & 16.0 & $\begin{array}{c}36.26 \\
\mathrm{P}<0.05 *\end{array}$ \\
\hline $\begin{array}{l}\text { 12-Hearing the sound of a bowel } \\
\text { movement by stethoscope every } 4 \text { hours }\end{array}$ & 44.0 & 56.0 & 79.0 & 21.0 & $\begin{array}{c}25.86 \\
\mathrm{P}<0.05 *\end{array}$ \\
\hline
\end{tabular}

P-value $<0.05 *$ Statistically significance

Table (4): Percentage Distribution of the Studied Nurses' performance regarding Vital Signs for Neonates with Sepsis pre/post- Program Implementation $(n=100)$

\begin{tabular}{|c|c|c|c|c|c|}
\hline \multirow{3}{*}{$\begin{array}{l}\text { Measuring vital } \\
\text { signs }\end{array}$} & \multicolumn{4}{|c|}{ Nurses' Practices } & \multirow{3}{*}{$\begin{array}{c}\mathbf{X}^{2} \\
\text { P-value }\end{array}$} \\
\hline & \multicolumn{2}{|c|}{ Pre-implementation program } & \multicolumn{2}{|c|}{ Post-implementation program } & \\
\hline & Competent & Incompetent & Competent & Incompetent & \\
\hline Temperature & 55 & 45 & 90 & 10 & $\begin{array}{c}15.7 \\
\mathrm{P}<0.05^{*}\end{array}$ \\
\hline Apical pulse & 63 & 37 & 87 & 13 & $\begin{array}{c}15.3 \\
\mathrm{P}<0.05 *\end{array}$ \\
\hline Respiratory rate & 63 & 37 & 89 & 11 & $\begin{array}{c}20.2 \\
\mathrm{P}<0.05^{*}\end{array}$ \\
\hline
\end{tabular}

P-value $<0.05 *$ statistically significance 
Table (5): Relation between total Nurses' Knowledge pre/post- Program Implementation and their Characteristics $(n=100)$

\begin{tabular}{|c|c|c|c|c|c|c|c|c|c|c|c|c|c|}
\hline \multirow{3}{*}{ Characteristics } & \multicolumn{6}{|c|}{ Pre- program implementation } & \multicolumn{6}{|c|}{ Post- program implementation } & \multirow{3}{*}{$\begin{array}{c}\mathbf{X}^{2} \\
\text { P-value }\end{array}$} \\
\hline & \multicolumn{2}{|c|}{ Good } & \multicolumn{2}{|c|}{ Average } & \multicolumn{2}{|c|}{ Poor } & \multicolumn{2}{|c|}{ Good } & \multicolumn{2}{|c|}{ Average } & \multicolumn{2}{|c|}{ Poor } & \\
\hline & No. & $\%$ & No. & $\%$ & No. & $\%$ & No. & $\%$ & No. & $\%$ & No. & $\%$ & \\
\hline \multicolumn{14}{|l|}{ Age } \\
\hline$<20$ & 1 & 11.0 & 7 & 17.0 & 11 & 21.0 & 1 & 6.0 & 6 & 28.0 & 12 & 18.0 & \multirow{3}{*}{$\begin{array}{l}5.73 \\
\mathrm{P}- \\
\text { value<.o5 }\end{array}$} \\
\hline $20-30$ & 7 & 77.0 & 26 & 65.0 & 37 & 72.0 & 13 & 86.0 & 11 & 52.0 & 46 & 71.0 & \\
\hline$\geq 30$ & 1 & 11.0 & 7 & 17.0 & 3 & 5.0 & 1 & 6.0 & 4 & 19.0 & 6 & 9.0 & \\
\hline \multicolumn{14}{|c|}{ Educational level } \\
\hline $\begin{array}{l}\text { School of } \\
\text { nursing }\end{array}$ & 1 & 11.0 & 7 & 17.0 & 6 & 11.0 & 9 & 14.0 & 2 & 3.0 & 3 & 20.0 & \multirow{3}{*}{$\begin{array}{l}.164 \\
\text { P- } \\
\text { value<05 }\end{array}$} \\
\hline $\begin{array}{l}\text { Technical } \\
\text { Institute }\end{array}$ & 2 & 22.0 & 8 & 20.0 & 11 & 21.0 & 14 & 21.0 & 5 & 7.0 & 2 & 13.0 & \\
\hline Bachelor & 6 & 52.0 & 25 & .65 .0 & 34 & 66.0 & 41 & 68.0 & 14 & 66.0 & 10 & 56.0 & \\
\hline \multicolumn{14}{|c|}{ Years of experience } \\
\hline $1<3$ & 6 & 50.0 & 23.0 & 52.0 & 28.0 & 54.0 & 36.0 & 76.0 & 11.0 & 52.0 & 10.0 & 66.0 & \multirow{3}{*}{$\begin{array}{c}.56 \\
\mathrm{P}- \\
\text { value<.o5 }\end{array}$} \\
\hline $3<5$ & 0 & 0.0 & 12.0 & 30.0 & 13.0 & 25.0 & 18.0 & 28.0 & 5.0 & 23.0 & 2.0 & 13.0 & \\
\hline$\geq 5$ & 3 & 33.0 & 5.0 & 12.0 & 10.0 & 19.0 & 10.0 & 15.0 & 5.0 & 23.0 & 3.0 & 20.0 & \\
\hline \multicolumn{14}{|l|}{ Marital status } \\
\hline Married & 7 & 67.0 & 30 & 75.0 & 40 & 78.0 & 49 & 89.0 & 18 & 85.0 & 10 & 66.0 & \multirow{3}{*}{$\begin{array}{c}.29 \\
\mathrm{P}- \\
\text { value<.o5 }\end{array}$} \\
\hline Single & 2 & 22.0 & 8 & 20.0 & 8 & 15.0 & 11 & 20.0 & 2 & 9.0 & 5 & 33.0 & \\
\hline Divorced & 0 & 0.0 & 2 & 5.0 & 3 & 5.0 & 4 & 7.0 & 1 & 4.0 & 0 & 0.0 & \\
\hline \multicolumn{14}{|l|}{ Training courses } \\
\hline Yes & 17 & 50.0 & 13 & 32.0 & 0 & 0.0 & 2 & 86.0 & 5 & 23.0 & 23 & 35.0 & \multirow{2}{*}{$\begin{array}{l}4.2 \\
\mathrm{P}- \\
\text { value<.o5 }\end{array}$} \\
\hline No & 34 & 66.0 & 27 & 67.0 & 9 & 87.0 & 13 & 13.0 & 16 & 76.0 & 41 & 64.0 & \\
\hline \multicolumn{14}{|l|}{ Place of work } \\
\hline $\begin{array}{l}\text { Benha } \\
\text { University } \\
\text { Hospital }\end{array}$ & 11 & 19.0 & 7 & 17.0 & 2 & 22.0 & 3 & 20.0 & 4 & 19.0 & 13 & 20.0 & \multirow{3}{*}{$\begin{array}{c}.62 \\
\text { P- } \\
\text { value<.o5 }\end{array}$} \\
\hline $\begin{array}{l}\text { Benha } \\
\text { Teaching } \\
\text { Hospital }\end{array}$ & 13 & 25.0 & 11 & 27.0 & 6 & 66.0 & 7 & 46.0 & 6 & 28.0 & 17 & 26.0 & \\
\hline $\begin{array}{l}\text { Benha } \\
\text { Specialized } \\
\text { Pediatric } \\
\text { Hospital } \\
\end{array}$ & 27 & 50.0 & 22 & 55.0 & 1 & 11.0 & 5 & 62.0 & 11 & 52.0 & 34 & 53.0 & \\
\hline \multicolumn{14}{|l|}{ Job position } \\
\hline Staff nurse & 40 & 78.0 & 36 & 90.0 & 6 & 66.0 & 12 & 80.0 & 20 & 95.0 & 50 & 78.0 & \multirow{2}{*}{$\begin{array}{l}5.8 \\
\text { P- } \\
\text { value<.o51 } \\
\end{array}$} \\
\hline $\begin{array}{l}\text { Supervisor } \\
\text { nurse }\end{array}$ & 11 & 20.0 & 4 & 19.0 & 3 & 33.0 & 3 & 21.0 & 1 & 4.0 & 14 & 21.0 & \\
\hline
\end{tabular}

\section{P-value $<0.05^{*}$ statistically significance}


Impact of Intervention Program on Nursing Performance Provided for Neonate with Sepsis at Intensive Care Units

Table (6): Relation between total Nurses' Performance pre/post- Program Implementation and their Characteristics $(n=100)$

\begin{tabular}{|c|c|c|c|c|c|c|c|c|c|}
\hline \multirow{3}{*}{ Characteristics } & \multicolumn{4}{|c|}{ Pre-program implementation } & \multicolumn{4}{|c|}{ Post- program implementation } & \multirow{3}{*}{$\begin{array}{c}X^{2} \\
\text { P-value }\end{array}$} \\
\hline & \multicolumn{2}{|c|}{ Competent } & \multicolumn{2}{|c|}{ Incompetent } & \multicolumn{2}{|c|}{ Competent } & \multicolumn{2}{|c|}{ Incompetent } & \\
\hline & No. & $\%$ & No. & $\%$ & No. & $\%$ & No. & $\%$ & \\
\hline \multicolumn{10}{|l|}{ Age } \\
\hline$<20$ & 9 & 21.0 & 10 & 16.0 & 17 & 19.0 & 9 & 14.0 & \multirow{3}{*}{$\begin{array}{l}.57 \\
\text { P- } \\
\text { value<.o5 }\end{array}$} \\
\hline $20<30$ & 27 & 62.0 & 43 & 72.0 & 51 & 70.0 & 6 & 64.0 & \\
\hline$\geq 30$ & 5 & 12.0 & 6 & 10.0 & 3 & 21.0 & 8 & 9.0 & \\
\hline \multicolumn{10}{|l|}{ Educational level } \\
\hline $\begin{array}{l}\text { School of } \\
\text { nursing }\end{array}$ & 9 & 14.0 & 34 & 57.0 & 0 & 0 & 14 & 16.0 & \multirow{3}{*}{$\begin{array}{l}5.8 \\
\text { P- } \\
\text { value<.o5 }\end{array}$} \\
\hline $\begin{array}{l}\text { Technical } \\
\text { Institute }\end{array}$ & 7 & 9.0 & 17 & 28.0 & 3 & 21.0 & 18 & 20.0 & \\
\hline Bachelor & 25 & 60.0 & 8 & 13.0 & 11 & 78.0 & 54 & 62.0 & \\
\hline \multicolumn{10}{|c|}{ Years of experience } \\
\hline $1<3$ & 27 & 65.0 & 30 & 50.0 & 10 & 76.0 & 47 & 54.0 & \multirow{3}{*}{$\begin{array}{l}5.9 \\
\text { P- } \\
\text { value<.o5 }\end{array}$} \\
\hline $3<5$ & 11 & 26.0 & 14 & 23.0 & 4 & 24.0 & 21 & 24.0 & \\
\hline$\geq 5$ & 3 & 7.0 & 15 & 25.0 & 0 & 0 & 18 & 20.0 & \\
\hline \multicolumn{10}{|l|}{ Marital status } \\
\hline Married & 23 & 56.0 & 44 & 74.0 & 9 & 79.0 & 68 & 64.0 & \multirow{3}{*}{$\begin{array}{l}1.05 \\
\text { P- } \\
\text { value<.o5 }\end{array}$} \\
\hline Single & 7 & 17.0 & 11 & 18.0 & 5 & 35.0 & 13 & 15.0 & \\
\hline Divorced & 1 & 2.0 & 4 & 6.0 & 0 & 0 & 5 & 5.0 & \\
\hline \multicolumn{10}{|l|}{ Training program } \\
\hline Yes & 23 & 56.0 & 44 & 74.0 & 28 & 82.0 & 13 & 19.0 & \multirow{2}{*}{$\begin{array}{l}3.73 \\
\mathrm{P}- \\
\text { value<<.05 }\end{array}$} \\
\hline No & 18 & 43.0 & 15 & 25.0 & 6 & 23.0 & 53 & 31.0 & \\
\hline \multicolumn{10}{|l|}{ place of work } \\
\hline $\begin{array}{l}\text { Benha University } \\
\text { Hospital }\end{array}$ & 4 & 9.0 & 16 & 27.0 & 1 & 7.0 & 19 & 22.0 & \multirow{3}{*}{$\begin{array}{l}6.3 \\
\mathrm{P}- \\
\text { value<.o5 }\end{array}$} \\
\hline $\begin{array}{l}\text { Benha Teaching } \\
\text { Hospital }\end{array}$ & 11 & 26.0 & 19 & 32.0 & 7 & 50.0 & 23 & 26.0 & \\
\hline $\begin{array}{l}\text { Benha } \\
\text { Specialized } \\
\text { Pediatric } \\
\text { Hospital }\end{array}$ & 26 & 63.0 & 24 & 40.0 & 6 & 42.0 & 44 & 51.0 & \\
\hline \multicolumn{9}{|l|}{ Job position } & \multirow{3}{*}{$\begin{array}{l}4.2 \\
P- \\
\text { value<.o5 }\end{array}$} \\
\hline Staff nurse & 30 & 71.0 & 45 & 76.0 & 12 & 85.0 & 70 & 81.0 & \\
\hline Supervisor nurse & 11 & 29.0 & 14 & 23.0 & 2 & 15.0 & 16 & 18.0 & \\
\hline
\end{tabular}

P-value $<0.05 *$ statistically significance

Table (7): Correlation between Total Scores of Nurses' Knowledge and Performance regarding Neonates with Sepsis pre/post- Program Implementation (n=100)

\begin{tabular}{|c|c|c|}
\hline \multirow{2}{*}{ Items } & \multicolumn{2}{|c|}{ Total knowledge } \\
\cline { 2 - 3 } & $\mathbf{r}$ & P-value \\
\hline Total practices & 0.662 & $<0.05^{*}$ \\
\hline
\end{tabular}

P-value $<0.05 *$ Statistically significance 


\section{Discussion}

Concerning to characteristics of the studied nurses the present study results revealed that (Table 1), more than two thirds of the studied nurses aged between $20<30$ years with mean and standard deviation was $23.9 \pm 3.8$ years. Also, all of the studied nurses were females and about two thirds of them had bachelor degree in nursing science. This finding was in agreement with Fayed (2016), in a study about Effect of Instructional Program on Nurses Compliance with Universal Precautions of Infection Control at NICUs in Egypt (El-Menoufia University) revealed that nearly two thirds of the studied sample aged between 20 to 39 years old. Such finding may be due to the unit nature, they prefer the newly graduate to work in the Neonatal Intensive Care Unit. Also, this finding was in agreement with Omar, (2016), found that, more than half of nurses had bachelor degree in a study about effect of instructional program on nurses compliance with universal precautions of infection control at NICUs in Egypt (Ain shams hospital). From the researcher's point of view, younger nurses were more motivated to acquire knowledge and had more capability of accepting new knowledge

Concerning nurses' knowledge about isolation measures used with neonates with sepsis, the current study revealed that (Table 2 ), less than quarter of the studied nurses had good knowledge about isolation measures used with neonates with sepsis pre- program implementation. Meanwhile, the majority of them had good knowledge about isolation measures used with neonates with sepsis post- program implementation. These findings were in agreement with Abd Elhady, (2015), found that, there was statistically improvement of nurses' knowledge regarding isolation measures when comparing with pre immediate implementation of teaching guidelines in study about impact of teaching guidelines on improving nurses' performance and patient's safety regarding nosocomial infection in pediatric unit in Egypt (Benha hospital) and also in agreement with Ghenaiem, (2011), showed an improvement in nurses' knowledge score regarding notification and isolation of infection post- program than preprogram with a statistically significant differences in a study about impact of designed infection control training program of knowledge and practice in Egypt (Benha hospital). This result could be due to that most of nurses in hospitals didn't receive any training program about isolation measures used with neonates with sepsis.

According to nurses' knowledge regardingperformance aboutwashing hands before dealing with neonates and before doing any deep intervention such as instillation of intravenous cannula the current study revealed that, the majority of studied nurses washing hands before dealing with neonates and before doing any deep intervention such as instillation of intravenous cannula on post- program implementation. This result was in agreement with Mulberry, (2011) who studied "Evaluation of waterless, scrub less chlorhexidine gluconate. Ethanol surgical scrub for antimicrobial efficacy" and Hirschmann, (2011) who studied "the influence of hand hygiene prior to insertion of peripheral venous catheters on the frequency of complications" and found that, hand decontamination should be performed using either an antimicrobial soap or an alcohol based hand rub immediately after entering the unite, before personal protective equipment and before handling an invasive devices for neonatal care.

Concerning to nurses' knowledge regarding performance, the current study viewed that, the majority of the studied nurses applied rules of infection control during preparation of medication, IV solutions, taken samples and instillation of intravenous catheter and changed the incubator and cleaned it for a premature 
child who spends 5 days and 7 days for the full term child on post- program implementation. On the same line Ibrahim et al., (2011) who studied "Assessment of infection control practices in neonatal intensive care unit" and revealed that, the majority of their studied group aware with, what infection is, and how it is transmitted. In the same line Diab, (2010) who studied "Exploring factors contributing to hazards of intravenous infusion and the actual nursing management in pediatric departments" and mentioned that the majority of nurses have good knowledge related to a septic techniques in intravenous therapy.

In relation to nurses' performance about vital signs for neonates with sepsis the present study revealed that (Table 4), less than half of the studied nurses had incompetent performance regarding vital signs pre- program implementation. While, the majority of them had competent performance regarding vital signs postprogram implementation. This finding was in agreement with El sayed, (2010),found that, more than three quarters of studied nurses had good performance about measuring vital signs after intervention in study about effect of educational program for nurses of pediatric care about care of critically ill children in Egypt (Ain shams university). In addition this finding was in agreement with Mostafa, (2010), who found that, no one of the studied nurses had poor performance in vital signs after intervention program, so it is a basic procedure in the assessment of the neonate in study about quality of nurses performance in neonatal intensive care units in Egypt (Benha hospital). This result could be due to that most of nurses in hospitals didn't receive any practical training program about competent procedure of vital signs.

In relation to the total mean scores of nurse's knowledge and performanceregarding their characteristics the current study found that (Table 5), there was statistical significant difference between nurses' knowledge, performanceand their characteristics as level of education and previous training. This reflects the need for enhancing knowledge of all nursing qualification categories and could emphasis the need for continuous training programs about infection control to facilitate adherence to infection control measures. In this regards Younis, (2010), documented that, an significant relation between nurses' knowledge and practices in study about infection control training program in the intensive care unit: An approach for nursing staff development" in Egypt (Ain shams hospital). These findings in agreement with Youssef, (2011), found that, there was highly significant relation between staff qualification knowledge and performance in a study about nosocomial infection and fever of unknown origin in pediatric hematology/ oncology unit in Egypt (Benha hospital). Also Royal Collage of Nursing, (2012), emphasized that, work places should have written policies about methods of utilizing standard precautions of infection control in order to provide guidance on all aspects of critically ill children care. As well, continuing education regardless of age can significantly improve infection control practices and reduces rates of infection in study about essential practice for infection prevention and control guidance for nursing staff in London. Meanwhile, this finding disagreement with El sayed, (2014), revealed that, there was no relation between knowledge and practice.

improvement in performance and characteristics of the studied nurses, the present study results revealed that (Table 6), there were statistical significant difference in total nurses' performancein relation to characteristics post-program implementation into; educational level, experience and attendance of training course. These findings were disagreement with Abdella, (2010), found that, nurses with longer years of experience had better practice regarding universal precaution in a study about nosocomial infection control training program of knowledge and practice in the 
intensive care unit in El- Gala Military Hospital in Egypt. In addition disagreed with Sultan, (2010), found that, there was an improvement in the level of performance with the increase in years of experience in study about assessment of nurses' awareness and attitude toward infection concept in Egypt

Concerning correlation between nurses' knowledge and performancepre/postprogram implementation the present study revealed that (Table 7), there was a positive correlation between nurses' knowledge and practice pre/post program implementation. This finding was disagreement with Serag, (2010), found that, no correlation between the knowledge and performance of nurses in a study about ventilator associated pneumonia. impact of designed training program on nurse's knowledge, practice and on patient outcome at ICU and Chan, (2010), reported that, no correlation between the knowledge and performance of nurses in his study about nurses knowledge and compliance with universal precautions in an acute hospital.

\section{Conclusion}

In the light of the present study findings, it can be concluded that, before implementation of intervention program the studied nurses had deficit knowledge and inadequate performance level related to care of neonates with sepsis. Meanwhile, after the intervention program, nurses' performance is significantly improved that reflects the importance of continuous and in- service education for nurses working at Neonatal Intensive Care Units.

\section{Recommendation}

In the light of the study findings, it was recommended that:

1- Periodical educational programs for nurses are necessary to help them to improve nurses' performance for care about neonates with sepsis at NICUs to alienate and reduce the complications of neonatal sepsis.

2-Providing resources and supplies in each study settings to help nurses to reach the competence level of practices.

3-Standardized nursing guideline about infection control should be used to guide the nurse for the management of neonates with sepsis.

4- Collaboration and continuing education of the staff in the NICUs are vital to improve the care provided for neonates.

5-Counselling services regarding prevention, detection and management of neonatal sepsis should be available in each study settings in addition to brochures, booklets, intervention media program containing simple information about needs and problems.

\section{Correspondence author name:}

NaglaaFathy Mohamed Belal

Pediatric Nursing, Faculty of Nursing, Benha University.

\section{References}

Abd ella, S. (2010): Nosocomial infection control system in El- Gala Military Hospital. Un published master thesis, Faculty of Nursing, Cairo University:pp.114-142.

Abd El-hady, M. (2015): Impact of teaching guidelines on improving nurses' performance and patient's safety regarding nosocomial infection in dialysis unit, Unpublished doctorate thesis, Faculty of Nursing, Benha University: p.210. 
Bowden, V., and Greenberg, C., (2012): Textbook of Pediatric Nursing Procedure, $3^{\text {rd }}$ ed., Lippincott Willams and Wilkins, London,PP.88-481

Burnett, E., Curran, E., Loveday, H., Keirnan, M. and Tannahill, M. (2013): The outcome competency framework for practitioners in infection prevention and control: Use of the outcome logic model for evaluation, J. Infection Prevention; 15(1): 14-21.

Camacho, A., Speaman, P. and Stoll, B. (2013):Neonatal infectious diseases: evaluation of neonatal sepsis, J. PediatrClin North Am ; 60(2): 367-89.

Chan, R. (2010): Nurses knowledge and compliance with universal precautions in an acute hospital, J. Nurse Stud; 39(2): 157-160.

Diab, S. (2010): Exploring factors contributing to hazards of intravenous infusion and the actual nursing management in pediatric departments in Shebin El-kom University Hospital, pp. 60-61.

Egyptian Ministry of Health and Population, (2015): Guidelines of infection control at Neonatal Intensive Care Units, $3^{\text {rd }}$ ed., Ministry of Health Press, pp.14-75.

El sayed, D. (2010): Pain management practices used by nurses working at neonatal Unpublished Master thesis, Ain shams university, Egypt: pp. 220-250.

El sayed, R. (2014): Studied nurses' compliance to infection control measures in surgical units at Benha University Hospital, Unpublished Master thesis, Faculty of Nursing, Benha University: p.67.

Fayed, S. (2016): Effect of Instructional Program on Nurses Compliance with Universal Precautions of Infection
Control at NICUs in Egypt, El-Menoufia University, Unpublished master thesis: pp. 60-61.12-Ghenaiem, S. (2011): Impact of designed infection control training program of knowledge and practice at Benha University Hospital. Unpublished Doctorate thesis, Faculty of Nursing, Benha University: pp.180-201.

Hirschmann, H. (2011): The influence of hand hygiene prior to insertion of peripheral venous catheters on the frequency of complications, J. of hospital infection; 49(15): 190-203.

Hospital Statistical Department, (2014): Benha Specialized Pediatric Hospital infection in neonate.

Ibrahim Y, Said A. and Hamdy G. (2011): Assessment of infection control practices in neonatal intensive care unit, The Egyptian Journal of Community medicine; 29(4): 27-45.

Khadka, S., Kisi, D., Raya, P., and Shrestha, S.( 2013): Fundamental of nursing procedure manual, $6^{\text {th }}$ ed., Japan International Cooperation Agency Office, PP.39-151.

Lindh, W., Pooler, M., Tamparo, C., Dahi, B. and Morries, J. (2014): Text book of Delmar's comprehensive medical assisting and clinical competencies, vital signs and measurement, $5^{\text {th }}$ ed., CengageLearing, chap (27), pp.743-747.

Marchant, E., Boyee, G., Sadarangani, M. and Lavoie, P. (2013): Neonatal sepsis due to Coagulase- Negative Staphylococci, J. Clinical and Developmental Immunology; 1(1): 10.

Mostafa, S. (2010):Quality of Nurses Performance in Neonatal Intensive Care Units, Pediatric Department, Master Thesis, Faculty of Nursing, Benha University, Egypt: pp. 57-83. 
Mulberry, G. (2011): Evaluation of waterless, scrublesschlorhexidinegluconate. Ethanol surgical scrub for antimicrobial efficacy, American J. of infection control; 29 (3): 377-382.-

Omar, T. (2016): Effect of instructional program on nurses compliance with universal precautions of infection control, J. Novel research in health care and nursing; 3(1): 81-92.

Royal College of Nursing, (2012): Essential practice for infection prevention and control guidance for nursing staff, London: RCN. Publication code: 004166.

Santos, A., Silva, M., Souza, N., Mota, G. and Franca, D. (2014): Nursing diagnoses of newborns with sepsis in a Neonatal Intensive Care Unit, J. Enfermagem Original; 22 (2): 255-261.

Serag, H. (2010): Ventilator associated pneumonia. Impact of designed training program on nurse's knowledge, practice and on patient outcome at ICU, Benha University Hospital, Doctorate Thesis, Faculty of Nurses: pp. 112-114.

Shah, B. and Padbury, J. (2014): Neonatal sepsis, J. Virulence; 5 (1): 170-178.
Shashi, G., Neelima, R., Sapre, Neha. And Masani, M. (2013): Incidence of neonatal sepsis in tertiary care hospital, J. Pediatr. India; 2 (3): pp. 548-552.

Silva, S., Motta, G., Nunes, C., Schardosim, J. and Cunha, M. (2015): Late- onset neonatal sepsis in preterm infants with birth weight, Orginal Papers, Available at: www. SciElo. Br/ scielo. Php? Pid, Assecced in 15-2-2016.

Sultan, T. (2010): Assessment of nurses' awareness and attitude toward infection concept at El Mania University Hospital, unpublished master thesis, faculty of nursing, cairo university: pp. 99-105.

Younis, A. (2010): Infection control training program: An approach for nursing staff development, Doctorate thesis, Faculty of Nursing, Ain shams University, Cairo, Egypt, p.89.

Youssef, A. (2011): Nosocomial infection and fever of unknown origin in pediatric. Hematology/ oncology unit Benha medical journal published by Faculty of Medicine Benha University; 26 (1): pp. 128. 